\title{
Pragmatic Competence and Activity-Based
} Language Teaching: Importance of Teaching Communicative Functions in Iraq EFL Context Nadhim Obaid Hussein ${ }^{1}$, Intan Safinas Mohd Ariff Albakri²*, Goh Hock Seng ${ }^{3 *}$

\author{
${ }^{1}$ Ph. D. Student, Faculty of Languages and Communication, University Pendidikan Sultan Idris, Kuala Lumpur, Malaysia \\ ${ }^{2}$ Assistant ProfessorDr., Faculty of Languages and Communication, University Pendidikan Sultan Idris, Tg. Malim Perak, \\ Malaysia \\ ${ }^{3}$ Assistant Professor. Dr., Faculty of Languages and Communication, University Pendidikan Sultan Idris, Tg. Malim Perak, \\ Malaysia
}

*Corresponding author

\begin{abstract}
The study attempted to explain the pragmatic competence and the role of teaching pragmatic through using activities-based teaching function of language in EFL context. The study was presented by a public curriculum lead that prioritizes the necessity for English teachers focused on activities when they teach pragmatic aspects in an academic communications. The study aimed to clarify the vital role of activity-based teaching pragmatic on improving students' communicative function of language among Iraqi EFL learners. Besides, most English learners fail to present pragmatic ability on how to use request, apology by relating expressions to their meanings, knowing the intention of language users. There is growing of studies on the value of activities-based teaching language on increasing students' pragmatic and function of language in EFL teaching.
\end{abstract}

Keywords_-Pragmatic competence, Activity-based teaching language, and EFL students.

\section{INTRODUCTION}

Communication is an indispensable part of any community life in which learners feel the need to interact with each other for certain aims. It is through the concept of language that learners can communicate with a number of conversers in a variety of contexts. However, while interacting, learners need to follow things beyond words, function of utterances, and communicative function of language. They need to know how to say something as well as when, where and to whom to say it. Therefore, communication is much more than putting some words in a linear order to form a set of items in various situations. Language learners are supposed to follow some conventions according to which their dialogue will be not only meaningful but also suitable. This analysis of how to say things in appropriate habits and places is essentially called pragmatics (Takkaç 2016).

As well as, pragmatics generally deals with what is beyond the dictionary meanings of statements; in other arguments, it is about what is truly meant with an utterance based on the norms and conventions of a specific society, or context, in which conversation takes place. Therefore, having a good command of the conventions enables the learner to establish and maintain effective and appropriate communication as well as understanding each other clearly (Yule, 1996) and this ability is usually referred as pragmatic competence.

Subsequent the shift in which the emphasis in language pedagogy changed from the linguistic-based to communicative-based purposes, the impact and status of pragmatic competence has regularly increased in educational circles. Considering pragmatic competence as a vital component of teaching communicative functions in EFL context, this study is intended to be a review on the value and place of pragmatic competence in general language competence and activity-based language teaching as a communicative-based purposes. For the purposes of this review, some core definitions proposed by prominent scholars about the term are presented followed by some studies, particularly latest ones, investigating diverse factors affecting pragmatic competence and the implication of teaching pragmatic in language education (Takkaç 2016).

Moreover, for it is comprehending and being understood communication among the persons. Adopting a teaching 
speech act of request to achieve this undertaking has placed more stress on accomplishing the practical component of the L2 along with its linguistic component (.Hussein \& Albakri, 2019). Also, a study byHussein \& Albakri (2019) confirmed that understanding only vocabulary or grammar is insufficient to be a competent language student in the social or academic communication. English learner considered as an excellent language student may not be able to communicate with learners of the target language. Hence, English learners need to understand and have communicative competence which comprises both language competence and pragmatic competence for accomplishing communication among different nationalities in different environments.

Furthermore, a study Hussein \& Albakri (2019) stated that pragmatic competence plays a vital role in acquiring diverse cultures of the foreign language, then it enable learners to understand communicative function of language. A study adopted by Bataineh and Hussein (2015) indicated pragmatic doesn't focus on grammatical knowledge, but it focuses on the meaning of students' language use in the acts of communication, as well as it focuses on helping the student to create meaning rather than improve perfectly grammatical structure or syntactic forms. Essentially, a study adopted by Hussein and Elttayef (2018) indicated that EFL students' pragmatic which is an aspect of communicative competence. Such pragmatic should be effectively and purposefully chosen in such a way that they should be more testable, teachable, interesting, motivating in FL classroom language (Hussein \& Albakri, 2019). Hence, it plays a vital role in obtaining different cultures or different traditions of foreign language. Through teaching pragmatic, English students can obtain different socio-cultural languages, communicative function of language by using activity-based teaching language. Sometimes, EFL learners show pragmatic competence when the written or spoken language produced is polite and socially suitable. Also, pragmatic competence is defined as the students' use of language and uses suitable rules and politeness dictated by the way it is understood by the student and express social or cultural request (Koike, 1989). In order to achieve the objectives of students' communication, and develop students' pragmatic ability in the EFL classroom (Hussein \& Albakri, 2019). Therefore, learners should recognize pragmatic instruction, and communicative function of language by using activity-based teaching language that learners employ in their utterances and discover strategies employed by the learners to achieve their communication objectives in different countries (Hussein \& Albakri, 2019). This may help foreign learners become more pragmatically and culturally aware of their own utterances, and provide insight into language instructors in order to develop EFL students' pragmatic competence in EFL circumstances (Hussein \& Albakri, 2019).

\section{THE RESEARCH PROBLEM}

In in the EFL setting, specific in Iraq setting, it was found the problem. EFL students in a college, whose first language is Arabic, seem to sometimes lack pragmatic ability when trying to speak in English or when teaching English course. In other words, our experience in teaching English as a foreign language in universities, and other educational institutions in Iraq has led me to believe that English language majors/graduates in Iraq have problems in using English for communication, not only in academic expressions but also even in situational conversions of street (Hussein \& Albakri, 2019). In the same view, although the increasing interest in teaching pragmatic in many forms of studies, a little in-depth study has been conducted on the effect of teaching pragmatic on Iraqi EFL students, where most of the foreign language teaching lacks adequate teaching pragmatic (Hussein \& Albakri, 2019). As a result, Iraqi learners seem less request or apology polite when communicating in the English language; more specifically when performing face-threatening acts (FTA) such as requesting (Hussein \& Albakri, 2019). As well as, a study adopted by Cohen (1996) and Hussein \& Albakri, (2019) stated that language learners can have all of the syntactic context and lexical items and still not be able to communicate their message because they lack the necessary pragmatic instruction to communicate their intent. Although some Iraqi learners seem pragmatically competent when speaking in the Arabic language, this competence is not necessarily reflected in their foreign language (Hussein \& Albakri 2019).

Accordingly, Iraqi learners need to learn pragmatic instruction and how to acquire socio-cultural request to permit them to make socio-cultural communication among different nationalities, and they also become more pragmatically and culturally aware of their own expressions (Hussein \& Albakri, 2019). With respect to use of pragmatic instruction among learners, the researcher saw through his experience in university, there is a tendency for learners to understand pragmatic competence and activity-based language teaching that is because importance of teaching activity enables learners to understand communicative function of language in EFL context. 


\section{THE AIM OF RESEARCH}

Just now, there has been a little empirical study into explanation the pragmatic competence and activity-based language teaching in Iraqi context, also explain the difference of functions of teaching pragmatic by using activity-based language. A part of a Ph.D. dissertation, the current paper aims to clarify main role of activity-based language teaching in EFL University. Activity-based language teaching is one of the new approaches that are popular in the area of pragmatics as it is more usually found in everyday learners' activity in diverse situations (Hussein \& Albakri, 2019). Consequently, identifying the pragmatic and activity-based language teaching made in the class may help Iraqi EFL undergraduates to be aware of activities that enable themto communicate effectively in the EFL environments? Additionally, results of diverse studies (Ellis, 1992; Hill, 1997; Jalilifar, 2009; Hussein \& Albakri, 2019) that focused on the importance of pragmatic and activity-based language teaching on increasing English learners' communicative functions of language.

\section{SIGNIFICANCE OF THE STUDY}

This study is significant as it deals with pragmatic competence and activity-based language teaching in Iraqi university. Identifying the activity-based English language teaching in college is a pre-step towards setting remedial action plan that contain some suggestions and essential strategies for better English teaching that may help learners in achieving the objectives of their language learning. The results of this study, and former results will be of a significant value to English teachers and researchers.

\section{REVIEW OF THE RELATED LITERATURE}

5.1 Former Researches on Pragmatics in EFL Learning and Teaching

Modern studies (Alcón-Soler, 2005; Rueda, 2006; Hussein \& Albakri, 2019) on pragmatics in EFL learning and teaching has stated that it is significant to help language learners to develop socio-cultural language, and use request to communicate effectivelyby using activities-based teaching language in diverseenvironments. As well as, a study stated by Hussein and Elttayef (2018) and Hussein and Albakri (2019) showed that EFL learners' pragmatic which is an aspect of communicative ability in the schoolroom. Such pragmatic should be successfully selected in such a way that they should be more testable, teachable, interesting, appealing in the FL schoolroom. An empirical study implemented by Bataineh and Hussein (2015) and Hussein\&
Albakri (2019) stated that pragmatic doesn't focus on grammatical knowledge, but it emphases on the meaning of students' language use in the acts of communication in EFL schoolroom. Therefore, various findings of those studies provided rich evidence to support the necessity for EFL learners' pragmatic and activity-based teaching language to develop communicative functions of language in the FL schoolroom.

Likewise, several researches have discovered the role of pragmatic instruction and activity-based teaching language on increasing English students' communicative functions of language in the EFL classroom (Bachman, 1990; Schmidt 1993; Bardovi-Harlig \& Hartford, 1997; Bataineh and Hussein, 2015; Hussein \& Albakri, 2019). A study was adopted by Bardovi-Harlig \& Dörnyei (1997) and Hussein \& Albakri (2019) showed that syntactic development does not confirm an equivalent level of pragmatic ability, and even excellent students may not be able to understand their intended objectives and contents in context (Eslami- Rasekh, 2005). For example, a language learners may pass any test or answer paper, but they are not able to convey the same language suitably in real-life situations because of the lack of pragmatic competence and don't teach pragmatic through activities.

Moreover, a study by Kasper (1989) stated that excellent students' communicative acts regularly had pragmatic failures and suggested that there was a need for teaching pragmatic to contain the application activity-based teaching communicative functions of language (Bardovi-Harlig \& Hartford, 1997; Bataineh and Hussein, 2015; Hussein \& Albakri 2019). Additionally, pragmatic instruction has been identified as one of the important instructions that help language students become positively competent in the application of request based on activity in different settings (Hussein \& Albakri, 2019).

Fundamentally, regarding pragmatic rising in the teaching of language, a number of activities are valued for pragmatic development and can be categorized into two main classes: activities to increase students' socio-cultural drills, and activities providing opportunities for communicative functions of language (Bardovi-Harlig \& Hartford, 1997). Concerning socio-cultural drills activities are those that have been proposed to grow recognition of how learners' language forms are used properly in setting (Eslami- Rasekh, 2005). For example, a study adopted by Schmidt (1993) stated socio-cultural drills activities that contains paying aware attention to linked certain practices, their pragmalinguistic purposes and the sociopragmatic constraints these specific 
forms contain. Also, other activities that offer opportunities for communicative function of language may contain group work, in-class discussions and cultural communications outside the lesson. Consequently, results revealed those two activities help to improve EFL students' socio-cultural language and enhance their communicative function of language in EFL context.

\subsection{Former Researches on Influenceof Pragmatic and} Activity-based Teaching Language onIncreasing Learners' Communicative Function of Language.

Pragmatic and activity-based teaching language played a vital role in risinglearners'communicative function of language in diverse contexts.Activities-based teaching languageare described as actions utilized in teaching English language especially pragmatic aspects (Oxford, 1993; Hussein \& Albakri, 2019). A study adopted by Oxford \& Nyikos (1989) indicated that role of activities of teaching pragmatic are often referred to as actions or applies that students utilize to remember what they have learned in the schoolroom, and they also help learners promote their own achievement in communicative function of language (Bremner, 1998; Hussein \& Albakri, 2019). As a result, learning put activities of teaching pragmatic forward by English students are crucial to English teachers as it can help them comprehend cultural request and function of language produced by students and reply suitably.

Additionally, prior studies have been conducted to discover out the implication of activity-based teaching pragmatic on developing learners' communicative function of language and usage of request in social and academic communication, the results of researches discovered that significant difference in mean scores, the results revealed that learners use suitable communicative function of language in post-test (Alcón-Soler, 2005; Rueda, 2006; Hussein \& Albakri, 2019).Also, a research adopted by Green and Oxford (1995: p.285) stated that "more proficient language learners use more learning social activities-based teaching pragmatic and more kinds of activities than less proficient language students". Thus, teaching of pragmatic by using activities not only help students become competent and communicative function of language, but they also develop students' pragmatic, the findings of studies discovered that learners who were taught activities-based teaching pragmatic scored better findings of communicative function of language in post-test (Hong-Nam \& Leavell, 2006; Alzeebaree \& Yavuz, 2017; Hussein \& Albakri, 2019). Consequently, the findings of earlier studies discovered the main role of pragmatic and activity-based teaching language on increasing students' communicative function of language in different situations.

Furthermore, numerous researches had provided that the learners were aware that learning activities were a portion of their language learning communicative function of language, the results showed that the learners showed more usage of communicative function of language and request in performing of social or academic dialogues, there was a significant difference in mean scores in post-test, learners scored better results in usage of communicative function of language (Yang, 1999; Hong-Nam and Leavell, 2006; Tuncer, 2009; Li, 2010; Alzeebaree \& Yavuz, 2017; Hussein \& Albakri, 2019). A research by Hussein \& Albakri (2019) also indicated that request strategies played an essential role in developing learners' knowledge of the requests particularly in different contexts. Teaching pragmatic by using activities s were the most prioritized actions that helped on increasing learners' communicative language in the EFL classes. Therefore, the results revealed that there was a statistically significant difference between the two groups (males and females) in the usage of communicative function of language.

Besides, it was adopted that pragmatic instruction by using activities-based teaching helped language students improve their communicative actions and socio-cultural language especially speech acts (Shridhar \& Shridhar, 1986, 1994; Sheorey, 1999; Alzeebaree \& Yavuz, 2017). Also, it was observed that activities-based teaching helped EFL students become more effective in their communicative situations mostly in-class debates. Also, the students' socio-cultural language influenced some of the activities-based teaching they used. A study was adopted by Yang (1999) identified quantitative evidence to find out English students' learning activity in the context of an indigenized form of English. Also, different studies concentrated on teaching pragmatic by using activities-based teaching in language learning have discovered that language learning activities are important to students on cultivating their communicative function of language (Griffiths, 2003; Ersözlü, 2010; Li, 2010; Purdie \& Oliver 1999; Y1lmaz, 2010). Furthermore, a study by Hussein \& Albakri (2019) revealed the essential role of request strategies for developing English learners' communicative language in the classroom. Hence, the findings of different findings displayed that strategies played an important role on increasing learners' socio-cultural language and communicative function of language. 


\section{CONCLUSION}

This current study has addressed the pragmatic and activitybased teaching language and its effects in EFL classroom, as well as its explanations and characteristics of activity-based teaching language on developing learners' communicative function of language. It has discovered researches on students' communicative function of language in EFL learning. The studies display a consensus that pragmatic knowledge can be taught effectively by using activities-based teaching language in EFL learning and teaching helps language students. Additionally, it has been declared that learners' different activities among learners, the results of data analysis revealed that there was a statistically significant difference among learners in the usage of communicative function of language. However, this summary also reveals that more investigation needs to be conducted in different studies to identify elements that may affect the way learners go about pragmatic development as well as the activities they utilize to obtain communicative function of language. Finally, depending on the various findings, the researcher tries to identify the role of pragmatic and activity-based teaching on developing students' communicative function of language. Then, he tries to put a suitable remedy for increasing communicative function of language in the EFL schoolroom.

\section{RECOMMENDATIONS FOR FUTURE STUDY}

The following recommendations could be adopted in the area of using activity-based language teaching in helping learners to develop their communicative function of language in EFL context.

\section{a) Recommendations Directed to the Ministry of Higher Education and scientific Research.}

1. The Ministry of Higher Education and scientific Research is advised to use activity-based language teaching in the curricula plans of the English language subject.

2. The Activity-based pragmatic teaching can be utilized for other English language courses at different scholastic levels and stages.

3. The Ministry of Higher Education and scientific Research may be called to hold training programs to assist EFL lecturers/ teachers in attaining ability to tackle activity content while teaching language and pragmatic contexts.

\section{b) Recommendations Directed to the Teachers}

1. Attention should be paid to the plans of activity-based pragmatic teaching into learning and teaching environments.

c) Recommendation Directed to the Researchers
1. More research is needed in the area of teaching pragmatic via using activity-based language teaching.

\section{REFERENCES}

[1] Alzeebaree, Y. \& Yavuz, M. (2017) Realization of the Speech Acts of Request and Apology by Middle Eastern EFL Learners. EURASIA Journal of Mathematics, Science and Technology Education ISSN: 1305-8223 (online) 1305-8215 (print).

[2] Alcón-Soler, E. (2005) 'Does instruction work for learning pragmatics in the EFL context?' System, 33(3), pp. 417-435. doi: 10.1016/j.system.2005.06.005.

[3] Bachman, L. (1990). Fundamental consideration in language testing. New York: Oxford University Press.

[4] Bardovi-Harlig, K., \& Dörnyei, Z. (1997). Pragmatic awareness and instructed L2 learning: An empirical investigation. Paper presented at the AAAL 1997 Conference, Orlando.

[5] Bardovi-Harlig, K., \& Hartford, B. (1997). Beyond methods: Components of second language teacher education. New York: McGraw-Hill.

[6] Bataineh, A. \& Hussein, N. (2015). The effect of using webcam chat on the undergraduate EFL students' pragmatic competence. International Journal of education. ISSIN 19484576. VO.7.NO.2.

[7] Bremner, S. (1998). Language learning strategies and language proficiency: Investigating the relationship in Hong Kong. Asian Pacific Journal of Language in Education, 1(2), 490-514.

[8] Byram, M. (Ed.). (2000). Routledge encyclopedia of language teaching and learning.

[9] London and New York: Routledge. Procedia Social and Behavioral Sciences, 2(2), 5147-5151.

[10] Canale, M. (1983). From communicative competence to language pedagogy. In J. Richards \& R. Schmidt (Eds.), Language and Communication (pp. 2-27). London: Longman.

[11] Cohen, A. D. (1996). Developing the ability to perform speech acts. Studies in Second Language Acquisition, 18, 253-267.

[12] Eslami-Rasekh, Z. (2005). Raising the pragmatic awareness of language learners. ELT Journal, 59(3), 199-208.

[13] Ersözlü, Z. N. (2010). Determining of the student teachers"e learning and studying strategies. Oxford: Oxford University Press.

[14] Eslami-Rasekh, Z. (2005). Raising the pragmatic awareness of language learners. ELT Journal, 59(3), 199-208.

[15] Ellis, R. (1992). The study of second language acquisition. Oxford: Oxford University Press.

[16] Green, J., \& Oxford, R. L. (1995). A closer look at learning strategies, L2 proficiency, and gender. TESOL Quarterly, 29(2), 261-297.

[17] Griffiths, C. (2003). Patterns of language learning strategy use. System, 31(3), 367-383. 
[18] Hill, T. (1997). The development of pragmatic competence in an EFL context. Dissertation Abstracts International, 58, 3905.

[19] Hong-Nam, K., \& Leavell, A. G. (2006). Language learning strategy use of ESL students in an intensive English learning context. System, 34(3), 399-415.

[20] Hussein, N and Elttayef, A (2018). The effect of authentic materials on developing undergraduate EFL students' communicative competence. Journal of literature, Languages and linguistic .ISSI 2422-8535.

[21] Hussein, N \& Albakri, I (2019). Iraqi Learners' Problems in Learning Speech Act of Request in EFL Classroom. Journal of Education and Practice. ISSN 2222-1735 (Paper) ISSN 2222-288X (Online) DOI: 10.7176/JEP Vol.10, No.4.

[22] Hussein, N \& Albakri, I (2019). The Essential Role of Teaching Pragmatic in the Iraqi EFL Classroom. Journal of Education and Practice. ISSN 2222-1735 (Paper) ISSN 2222288X (Online) DOI: 10.7176/JEP Vol.10, No.4, 2019.

[23] Hussein, N, .Albakri, I (2019). The importance of the speech act of request in the Iraqi EFL classroom. International Journal of English Research ISSN: 2455-2186. Volume 5; Issue 2; Page No. 95-98.

[24] Hussein, N, .Albakri, I (2019). The Role of Strategies on Developing Iraqi Learners' Usage of Request in EFL Classroom. International Journal of English, Literature and Social Science (IJELS)ISSN: 2456-7620.Vol-4, Issue-5, Sep Oct 2019.

[25] Hussein, N, .Albakri, I (2019). The Importance of the Request Strategies in the Iraqi EFL Classroom. International Journal of Applied Linguistics \& English Literature. E-ISSN: 22003452 \& P-ISSN: 2200-3592.V.8n. 2p.8.

[26] Hymes, D. (1972). On communicative competence. In J. B. Pride \& J. Holmes (Eds.), Sociolinguistic (pp.269-285). Harmon sworth: Penguin.

[27] Jalilifar, A. (2009). Request strategies: Cross-sectional study of Iranian EFL learners and Australian native speakers. English Language Teaching, 2,461.

[28] Kasper, G. (1989). Variation in interlanguage speech act realization. In S. Gases, C. Madden,

[29] Krasner, I. (1999). The role of culture in language teaching. Dialog on Language Instruction, 13(1-2), 79-88.

[30] Koike, D.A. (1989). Pragmatic competence and adult L2 acquisition: Speech acts in interlanguage. The Modern Language Journal, 73(3), 279-289.

[31] Kurdghelashvili, $T$ (2015) Speech Acts and Politeness Strategies in an EFL Classroom in Georgia. World Academy of Science, Engineering and Technology International Journal of Cognitive and Language Sciences .Vole: 9, No: 1

[32] Leung, C (2005).Convivial communication: decontextualizing communicative competence. International Journal of Applied Linguistics, vo.15, no.2, 119-144.
[33] Liu, A. (2010). On pragmatic "borrowing transfer" evidence from Chinese EFL learners' compliment response behavior. Chinese Journal of Applied Linguistics, 33(4), 26-44.

[34] Oxford, R. L. (1993). Research on second language learning strategies. Annual Review of Applied Linguistics, 13, 175-187.

[35] Oxford, R. L., \& Nyikos, M. (1989). Variables affecting choice of language learning strategies by university students. Modern Language Journal, 73, 404-419.

[36] Purdie, N., \& Oliver, R. (1999). Language learning strategies used by bilingual school-aged children. System, 27(3), 375388.

[37] Rueda, Y. (2006) 'Developing pragmatic competence in a foreign language', Colombian Applied Linguistics Journal, 8, pp. 169-182.

[38] SafontJordà, M. P. (2005). Third Language Learners: Pragmatic production and awareness. Clevedon: Multilingual Matters.

[39] Schmidt, R. (1993). Consciousness, learning and interlanguage pragmatics. In G. Kasper

[40] Sheorey, R. (1999). An examination of language learning strategy use in the setting of an indigenized variety of English. System, 27(2), 173-190.

[41] Shridhar, K., \& Shridhar, S. (1986). Bridging the paradigm gap: Second language acquisition theory and indigenized varieties of English. World Englishes, 5, 3-14.

[42] Takkaç Tulgar, A. (2016). The role of pragmatic competence in foreign language education. Turkish Online Journal of English Language Teaching (TOJELT), 1(1), 10-19.

[43] Tuncer, U. (2009). How do monolingual and bilingual language learners differ in use of learning strategies while learning a foreign language? Evidences from Mersin University. Procedia Social and Behavioral Sciences, 1(1), 852-856.

[44] Vellenga, H. (2004). Learning pragmatics from ESL and EFL textbooks: How likely? TESL- Electronic Journal, 8(2), 1-18.

[45] Verschueren, J. (1999). Understanding pragmatics. London, New York, Sydney: Arnold.

[46] Yang, N. D. (1999). The relationship between EFL learners' beliefs and learning strategy use. System, 27(4), 515-535.

[47] Y1lmaz, C. (2010). The relationship between language learning strategies, gender, proficiency and self-efficacy beliefs: A study of ELT learners in Turkey. Procedia Social and Behavioral Sciences, 2(2), 682-687.

[48] Yule, G. (1996). Pragmatics. Oxford: Oxford University Press. 